\title{
Pengaruh Penambahan Sari Buah Pisang Ambon (Musa paradisiaca) sebagai Perisa Alami terhadap Warna, Total Padatan Terlarut dan Sifat Organoleptik Yogurt
}

\author{
The Effect of Additional Ambon Banana Juice (Musa paradisiaca) as a Natural Flavour \\ Toward Color, Total Dissolved Solid and Organoleptic Properties of Yogurt
}

\author{
S. R. Zulaikhah, dan R. Fitria \\ Universitas Nahdlatul Ulama Purwokerto \\ Jln. Sultan Agung No. 42 Karangklesem Purwokerto Selatan, Banyumas \\ Corresponding e-mail: rahmawatidjunaidi0@gmail.com
}

\begin{abstract}
The purpose of this study was to obtain data on the effect of additional natural Ambon banana fruit juice toward the color, total solution solids and organoleptic properties (color and viscocity) of yogurt. The experimental design used was a non factorial randomized block design with the addition of levels of natural Ambon banana fruit juice $(0 \%, 2 \%, 4 \%$ and $6 \%)$ with blocks of 3 times. Data for color and total dissolved solids of yogurt if there was a significant effect $(\mathrm{P}<0.05)$ due to the level of fruit juice addition, then further tested with the Duncan test. The organoleptic test used the Kruskal-Wallis non-parametric test, if there was a significant effect, the Man Whitney continued test was carried out. Panelists as many as 30 people are classified as somewhat trained, consisting of students from several universities in Purwokerto. The results showed that the addition of Ambon banana juice as much as $0,2,4$ and $6 \%$ had no significant effect on the physical properties of color $(\mathrm{L} * \mathrm{a} * \mathrm{~b} *)$ and the total dissolved solids of yogurt. However, when viewed from the mean value, the increase in the addition of Ambon banana juice will reduce the brightness of the yogurt, the color from green to less and to red, and the color increasingly towards yellow, the total solid also increased. The results of the organoleptic analysis test on color showed a significant effect between T0 treatment (without the addition of Ambon banana juice) with T1, $\mathrm{T} 2$ and T3, but between the addition of Ambon banana juice 2, 4, and $6 \%$ there was no significant effect $(\mathrm{P}>0.05)$. The effect of the addition of banana juice treatment did not have a significant effect on the organoleptic test for viscosity of yogurt.
\end{abstract}

Key words: Yogurt, ambon banana, color, total dissolved solids, organoleptic properties

\begin{abstract}
ABSTRAK
Penelitian bertujuan untuk memperoleh data mengenai pengaruh penambahan sari buah alami pisang Ambon terhadap warna, total padatan terlarut dan sifat organoleptik (warna dan kekentalan) yogurt. Rancangan Percobaan yang digunakan adalah Rancangan Acak Kelompok non faktorial dengan perlakuan level penambahan sari buah alami pisang Ambon $(0 \%, 2 \%, 4 \%$ dan 6\%) dengan blok sebanyak 3 kali. Data untuk warna dan total padatan terlarut yogurt apabila terjadi pengaruh yang nyata $(\mathrm{P}<0,05)$ karena level penambahan sari buah maka diuji lanjut dengan uji Duncan. Uji organoleptik menggunakan uji non parametrik KruskalWallis, bila terjadi pengaruh yang nyata maka dilakukan uji lanjut Man Whitney. Panelis sebanyak 30 orang tergolong agak terlatih yang terdiri dari mahasiswa dari beberapa perguruan tinggi di Purwokerto. Hasil penelitian menunjukkan bahwa perlakuan penambahan sari buah pisang Ambon sebanyak 0, 2, 4 dan 6\% tidak berpengaruh nyata terhadap sifat fisik warna $\left(\mathrm{L}^{*} \mathrm{a}^{*} \mathrm{~b}\right)$ dan total padatan terlarut yogurt. Tetapi apabila dilihat dari nilai reratanya dengan kenaikan penambahan sari buah pisang Ambon akan mengurangi kecerahan yogurt, warna dari kehijauan berkurang dan menuju ke merah, dan warna semakin menuju kekuningan, total padatan juga mengalami kenaikan. Hasil uji analisis organoleptik terhadap warna terjadi pengaruh yang nyata antara perlakuan T0 (tanpa penambahan sari buah pisang Ambon) dengan T1, T2 dan T3, namun antara penambahan sari buah pisang Ambon 2, 4, dan $6 \%$ tidak terdapat pengaruh yang nyata $(\mathrm{P}>0,05)$. Perlakuan penambahan sari buah pisang tidak terjadi pengaruh yang nyata terhadap uji organoleptik kekentalan yogurt.
\end{abstract}

Kata kunci: Yogurt, pisang ambon, warna, total padatan terlarut, sifat organoleptik

\section{PENDAHULUAN}

Pengolahan susu segar menjadi yogurt adalah salah satu usaha diversifikasi pangan fungsional. Yogurt merupakan hasil olahan susu dengan proses fermentasi oleh Bakteri Asam Laktat (BAL), yang mengubah laktosa susu menjadi asam laktat. Gahruie et al. (2015) dalam 
Ismawati et al. (2016) menyatakan bahwa yogurt banyak mengandung nutrisi berupa protein, lemak, kalsium, potassium, vitamin B (B1, B2, B6, asam nicotinic dan pantothenic) tetapi sedikit zat besi, vitamin $\mathrm{C}$, karotenoid dan serat pangan. BAL yang sering digunakan adalah Streptococcus thermophillus dan Lactobacillus bulgaricus, kadang ditambah dengan Lactobacillus acidophilus.

Ada suatu istilah yogurt sinbiotik, karena memadukan yogurt probiotik dengan tambahan prebiotik. Probiotik merupakan mikroorganisme yang dalam jumlah banyak akan menghasilkan dampak positif bagi kesehatan tubuh. Prebiotik merupakan bahan makanan yang terfermentasi yang memberikan perubahan khas, baik pada komposisi (Gibson et al., 2004 dalam Karlin et al., 2014). Salah satu sumber prebiotic adalah FOS (Frukto-oligosakarida) yang merupakan golongan oligosakarida yang tidak tercerna, sehingga digolongkan menjadi serat pangan. Sumber FOS yang relative tinggi dan banyak ditemukan di Indonesia adalah pisang, terutama pada pisang matang. Menurut Bouhnik et al. (2007) dalam Karlin et al. (2014) menyatakan bahwa penambahan 1\% frukto-oligosakarida dapat meningkatkan jumlah BAL (Streptococcus thermophilus, Lactobacillus acidophilus, dan Bifidobacterium sp.).

Kandungan gizi pisang ambon dalam 100 $\mathrm{g}$ bahan yaitu protein $1,2 \%$, lemak $0,3 \%$, mineral $0,8 \%$, serat $0,4 \%$ dan karbohidrat $27,2 \%$. Pisang Ambon mengandung vitamin dan mineral seperti vitamin C, B kompleks, B6, serotonin, kalium, magnesium, fosfor, besi, dan kalsium (Almatsier, 2001 dalam Asih et al., 2018).

Pisang Ambon adalah salah satu jenis pisang yang banyak dan mudah didapatkan di Indonesia, dengan penelitian ini diharapkan dapat meningkatkan manfaat potensi lokal dari pisang Ambon. Penelitian ini juga diharapkan memperoleh data mengenai pengaruh penambahan sari buah alami pisang Ambon terhadap warna, total padatan dan sifat organoleptik yogurt.

\section{MATERI DAN METODE}

Pelaksanaan penelitian di Laboratorium Teknologi Hasil Ternak Fakultas Peternakan, Universitas Jenderal Soedirman, Purwokerto. Menggunakan susu sapi segar sebagai bahan utama membuat yogurt, kultur starter menggunakan kultur konvensional dengan kandungan 3 bakteri yaitu Streptococcus thermophillus, Lactobacillus bulgaricus dan Lactobacillus acidophilus, dan pisang Ambon sebagai perisa alami. Rancangan penelitian untuk menggunakan rancangan acak kelompok non factorial dengan perlakuan penambahan sari buah pisang Ambon sebanyak 0\% (T0), 2\% (T1), 4\% (T2) dan 6\% (T3), untuk bloknya dilakukan sebanyak 3 kali. Apabila terjadi pengaruh yang nyata maka dilakukan uji lanjut Duncan. Uji organoleptik menggunakan uji non parametrik Kruskal-Wallis, bila terjadi pengaruh yang nyata maka dilakukan uji lanjut Man Whitney. Panelis sebanyak 30 orang tergolong agak terlatih yang terdiri dari mahasiswa dari beberapa perguruan tinggi di Purwokerto.

\section{Pembuatan Sari Buah Pisang Ambon}

Pembuatan sari buah pisang Ambon mengacu pada Ichwansyah (2014) dengan modifikasi. Modifikasi dilakukan dengan pemanasan atau pasteurisasi pada suhu $88^{\circ} \mathrm{C}$ selama 15 detik, setelah pisang Ambon matang penuh diblender dan disaring.

\section{Pembuatan Yogurt Buah Pisang}

Pembuatan yogurt buah pisang Ambon ini mengacu pada Ichwansyah (2014) dengan modifikasi. Susu segar dipasteurisasi pada suhu $75^{\circ} \mathrm{C}$ selama 15 detik, kemudian sari buah pisang dimasukkan sesuai dengan level perlakuan penambahan sari buah pisang $(0,2,4$ dan $6 \%)$ dihomogenkan dan dimasukkan starter sebanyak $5 \%(\mathrm{v} / \mathrm{v})$ setelah itu diinkubasi pada suhu $42^{\circ} \mathrm{C}$ selama 4 jam. Setelah itu yogurt buah tersebut dimasukkan ke refrigerator, kemudian dilakukan pengujian.

\section{Uji Warna}

Pengujian warna yogurt dilakukan dengan menggunakan alat Colorimeter CS-10 Serial No. A1111980798. CHN Spec. Sampel yogurt dimasukkan Erlenmeryer dimasukkan pada alat sebanyak $50 \mathrm{ml}$, kemudian color reader ditempelkan pada permukaan sampel. Tombol pembacaan diatur pada $\mathrm{L}^{*}$ (lightness), $\mathrm{a}^{*}$ (redness) dan $\mathrm{b}^{*}$ (yellowness) dan tombol target ditekan. Hasil dari pembacaan alat dicatat (Wibawanti dan Rinawidiastuti, 2018).

\section{Pengujian Total padatan}

Pengukuran total padatan terlarut mengacu metoda yang dilakukan oleh Ismawati, et al. (2016) menggunakan refraktometer menurut SNI 01-3546-2004. Total padatan terlarut yogurt diukur dengan refraktometer 
genggam (Master Refractometer Manual ATAGO, Tokyo Japan) pada suhu $25{ }^{\circ} \mathrm{C}$ dan dilakukan kalibrasi menggunakan aquades. Sebanyak 1-2 tetes sampel diletakkan pada prisma refraktometer, kemudian hasil langsung bisa dibaca. Jumlah kandungan padatan terlarut dinyatakan sebagai Brix.

\section{Pengujian Organoleptik}

Pengujian organoleptik dilakukan oleh 30 orang panelis agak terlatih. Panelis diminta untuk menilai warna dan kekentalan yogurt buah pisang Ambon. Metode yang digunakan adalah dengan mempersiapkan sampel terlebih dahulu dengan menempatkan sampel pada cup kecil ukuran $50 \mathrm{ml}$. Tabel penilaian disediakan dalam bentuk form kuisioner. Untuk uji warna dengan rentang nilai 1 sampai 5 , nilai 5 yaitu sangat menarik, nilai 4 yaitu menarik, nilai 3 yaitu agak menarik, nilai 2 yaitu tidak menarik dan nilai 1 yaitu sangat tidak menarik. Uji kekentalan yogurt dengan rentang nilai 1 sampai 5 , nilai 5 yaitu sangat kental, nilai 4 yaitu kental, nilai 3 yaitu biasa, nilai 2 yaitu agak kental dan nilai 1 yaitu tidak kental.

\section{HASIL DAN PEMBAHASAN}

\section{Total Padatan Terlarut}

Total padatan adalah banyaknya padatan yang terdapat pada yogurt sari buah pisang Ambon. Proses fermentasi bakteri asam laktat menghasilkan metabolit berupa asam laktat. Menurut Fardiaz (2003) dalam Ismawati et al., (2016) menyatakan bahwa metabolit tersebut (asam laktat) akan tersekresikan keluar sel dan akan terakumulasi dalam cairan hasil fermentasi. Total padatan terlarut berupa sisa hasil total gula, asam laktat dan asam organik yang terbentuk. Hasil total padatan yogurt dapat dilihat di Table 1.

Tabel 1. Rata-rata total padatan terlarut yogurt sari buah pisang Ambon

\begin{tabular}{ccccc}
\hline \multirow{2}{*}{ Perlakuan } & \multicolumn{3}{c}{ Blok } & \multirow{2}{*}{ Rataan } \\
\cline { 2 - 4 } & 1 & 2 & 3 & \\
\hline T0 & 8 & 9 & 9 & 8,67 \\
T1 & 9 & 9 & 8 & 8,67 \\
T2 & 9 & 10 & 8 & 9,00 \\
T3 & 10 & 10 & 9 & 9,67 \\
\hline Rataan & 9 & 9,5 & 8,5 & 9,00 \\
\hline Keterangan: Tidak terdapat pengaruh perlakuan \\
penambahan level pisang terhadap kimia \\
yogurt $(\mathrm{P}>0,05)$
\end{tabular}

Berdasarkan hasil analisis ragam terhadap pengukuran total padatan terlarut yogurt, ternyata penambahan sari buah pisang dengan level 2, 4 dan $6 \%$ tidak memberikan pengaruh yang nyata $(\mathrm{P}>0,05)$. Total padatan yang diperoleh yaitu antara $8,667-9,667$ Brix. Dilihat dari rerata menunjukkan nilai total padatan terlarut yang semakin meningkat.

Hasil analisis yang tidak nyata ini diduga karena rentang penambahan level sari buahnya terlalu sedikit, sehingga perubahannya tidak nyata walaupun rerata menunjukkan kenaikan. Terjadi kenaikan walaupun sedikit ini dikarenakan peningkatan sari buah menyebabkan jumlah total padatan terlarut (TPT) yang dihasilkan semakin meningkat pula, karena selama berlangsungnya proses fermentasi laktosa dan sukrosa akan dirombak oleh kultur starter. Hal ini dikarenakan pisang Ambon memiliki sejumlah padatan terlarut sehingga apabila ditambahkan dalam pembuatan yoghurt, padatan terlarut dalam yoghurt meningkat. Hal ini sesuai penelitian dari Novidahlia et al. (2018) semakin meningkatnya penggunaan jumlah pisang, maka jumlah total padatan terlarut (TPT) semakin tinggi dikarenakan pada buah matang termasuk pisang, gula merupakan komponen utama padatan terlarut. Gula yang terbentuk merupakan hasil pemecahan pati, sehingga akan meningkatkan kandungan gula dan pada akhirnya akan menyebabkan peningkatan TPT.

\section{Uji Warna Lightness (L) Warna Yogurt}

Nilai kecerahan atau lightness (L) dinyatakan dalam kisaran 0-100, nilai menuju ke angka 0 menunjukkan warna menuju ke hitam, sedangkan nilai menuju ke angka 100 menunjukkan warna ke putih atau cerah (Wibawanti dan Riniwidiastuti, 2018). Rerata nilai lightness atau kecerahan warna yogurt dapat dilihat dalam table 1.

Tabel 2. Uji lightness (L) warna yogurt dengan penambahan sari buah pisang Ambon

\begin{tabular}{ccccc}
\hline \multirow{2}{*}{ Perlakuan } & \multicolumn{3}{c}{ Blok } & \multirow{2}{*}{ Rataan } \\
\cline { 2 - 4 } & 1 & 2 & 3 & \\
\hline T0 & 61,63 & 66,45 & 73,92 & 67,33 \\
T1 & 57,12 & 76,67 & 73,21 & 69,00 \\
T2 & 49,88 & 70,34 & 77,98 & 66,06 \\
T3 & 55,24 & 77,06 & 71,63 & 67,98 \\
\hline Rataan & 55,97 & 72,63 & 74,18 & 67,59 \\
\hline
\end{tabular}

Keterangan: Perlakuan penambahan sari buah tidak berpengaruh nyata $(\mathrm{P}>0.05)$ 
Data hasil penelitian ini menunjukan bahwa rerata nilai kecerahan (L) pada yoghurt akibat penambahan sari buah pisang berkisar antara $67,33-69$.

Hasil analisis ragam pengukuran tingkat kecerahan (L) bahwa yogurt buah yang diberikan sari buah pisang Ambon menunjukkan adanya pengaruh yang tidak nyata $(\mathrm{P}>0.05)$, yang berarti dengan penambahan level sari buah pisang sampai level $6 \%$ belum menunjukkan pengaruh yang nyata terhadap kecerahan yogurt. Hal ini diduga karena homogenisasi saat penambahan sari buah pisang dilakukan dengan baik sehingga semua partikel tersebar dengan baik dan tingkat reaksi browning enzimatis saat pembuatan sari buah sangat kecil kemungkinan karena ditambahkan vitamin $\mathrm{C}$ saat pengolahan. Azzahra dan Nisa (2016) menyatakan bahwa pisang yang dipotong-potong menyebabkan enzim dapat kontak dengan substrat berupa asam amino tirosin dan komponen-komponen fenolik sehingga dapat terjadi reaksi oksidasi dan warna pisang berubah menjadi kecoklatan.

\section{Uji Warna Redness atau merah-hijau $\left(a^{*}\right)$ Yogurt}

Warna kemerahan direpresentasikan oleh nilai a yang menunjukan tingkat kemerahan dengan kisaran nilai -100 sampai +100 , nilai positif $(+)$ menyatakan kecenderungan warna kemerahan, sedangkan nilai negatif (-) menyatakan kecenderungan warna kehijauan (Pomeranz dan Meloan, 1994 dalam Widagdha dan Nisa, 2015). Rerata nilai Redness atau kemerahan warna yogurt dapat dilihat dalam table 3 .

Tabel 3. Uji Redness (a*) warna yogurt dengan penambahan sari buah pisang Ambon

\begin{tabular}{cllll}
\hline \multirow{2}{*}{ Perlakuan } & \multicolumn{4}{c}{ Blok } \\
\cline { 2 - 4 } & \multicolumn{1}{c}{1} & \multicolumn{2}{c}{2} & \\
\hline P1 & $-7,595$ & $-6,66$ & $-6,215$ & $-6,8233$ \\
P2 & $-7,23$ & $-5,46$ & $-6,435$ & $-6,375$ \\
P3 & $-6,885$ & $-6,33$ & $-5,535$ & $-6,25$ \\
P4 & $-6,835$ & $-5,745$ & $-6,495$ & $-6,3583$ \\
Rerata & $-7,1363$ & $-6,0488$ & $-6,17$ & $-6,4517$ \\
\hline
\end{tabular}

Keterangan: Perlakuan penambahan sari buah tidak berpengaruh nyata $(\mathrm{P}>0.05)$

Berdasarkan analisis variansinya menunjukkan bahwa penambahan sari buah pisang Ambon tidak berpengaruh nyata $(\mathrm{P}>0,05)$ terhadap warna kemerahan yogurt. Rerata nilai kemerahan (a) yoghurt akibat penambahan sari buah pisang berkisar antara -6,25 sampai -6,8233. Hal ini menunjukkan bahwa yogurt yang dihasilkan berada pada warna kehijauan, namun dengan penambahan sari buah pisang $(2,4$ dan $6 \%)$ menunjukkan ke arah warna merah karena nilai warna hijaunya berkurang. Hal ini disebabkan karena dalam buah pisang mengandung saponin, glikosida, tanin, alkaloid, dan flavonoid (Ariani dan Linawati, 2016 dalam Haryatmi et al. 2017). Pengaruh penambahan sari buah pisang terhadap redness atau merahhijau (a*) yogurt dapat dilihat pada gambar 2, karena hasil menunjukkan negatif (-) maka gambar diberi keterangan dengan kehijauan.

\section{Uji Warna Yellowness atau Kuning-biru (b*)}

Warna kekuningan direpresentasikan oleh nilai b yang menunjukan tingkat kekuningan dengan kisaran nilai -100 sampai +100 , nilai positif menyatakan kecenderungan warna kekuningan, sedangkan nilai negatif menyatakan kecenderungan warna kebiruan (Pomeranz dan Meloan, 1994 dalam Widagdha dan Nisa, 2015). Rerata nilai warna Yellowness atau Kuning-biru (b*) yogurt dapat dilihat dalam table 3 .

Tabel 4. Rerata nilai Yellowness atau Kuningbiru $\left(b^{*}\right)$ warna yogurt dengan penambahan sari buah pisang Ambon

\begin{tabular}{ccccc}
\hline \multirow{2}{*}{ Perlakuan } & \multicolumn{3}{c}{ Blok } & Rerata \\
\cline { 2 - 4 } & 1 & 2 & 3 & \\
\hline T0 & 7,95 & 10,57 & 9,61 & 9,37 \\
T1 & 8,56 & 10,03 & 9,46 & 9,35 \\
T2 & 7,15 & 10,20 & 9,41 & 8,92 \\
T3 & 8,48 & 9,11 & 9,21 & 8,93 \\
Rerata & 8,04 & 9,98 & 9,42 & 9,14 \\
\hline
\end{tabular}

Keterangan: Perlakuan penambahan sari buah tidak berpengaruh nyata $(\mathrm{P}>0.05)$

Berdasarkan hasil analisis yang telah dilakukan diperoleh rerata nilai kekuningan $\left(\mathrm{b}^{*}\right)$ yoghurt akibat penambahan sari buah pisang berkisar antara 8,92-9,37. Nilai tertinggi warna kekuningan ini pada T0 atau tanpa penambahan sari buah pisang, hal ini diduga karena warna beta karoten susu masih tinggi.

\section{Uji Organoleptik terhadap Warna}

Warna merupakan komponen yang sangat penting dalam menentukan kualitas atau derajat penerimaan dari suatu bahan pangan, karena menurut Wahyudi (2006) dalam Aprilia et al. (2019) kesan yang baik terhadap suatu produk bahan pangan karena memiliki warna 
yang menarik, walaupun belum tentu memiliki rasa yang enak. Uji organoleptik warna pada penelitian ini tersaji dalam Tabel 5.

Tabel 5. Analisis uji organoleptik warna penambahan sari buah pisang pada yogurt

\begin{tabular}{ccc}
\hline Perlakuan & Rataan $+/-$ SD & Nilai P \\
\hline T0 & $3.48 \pm 0.753^{\mathrm{a}}$ & $0.017^{*}$ \\
T1 & $3.23 \pm 0.849^{\mathrm{ab}}$ & \\
T2 & $3.21 \pm 0.814^{\mathrm{b}}$ & \\
T3 & $3.13 \pm 0.706^{\mathrm{b}}$ & \\
\hline
\end{tabular}

Keterangan: $\left(^{*}\right)$ Terdapat pengaruh perlakuan pada uji Kuskal Wallis pada taraf signifikansi $5 \%$ dan angka yang diikuti huruf yang sama tidak berbeda nyata pada uji Man Whitney

Berdasarkan analisis data organoleptik tentang warna, menunjukkan bahwa penambahan sari buah berpengaruh terhadap warna. Uji lanjut menunjukkan bahwa terdapat perbedaan yang nyata pada yogurt yang tanpa penambahan sari buah pisang Ambon (T0) dengan T1, T2 dan T3. Namun pada penambahan 2, 4 dan 6\% tidak terjadi perbedaan yang nyata. Hal ini karena pada pada T0 yogurt berwarna lebih putih sehingga penilaian panelis membuat lebih menarik karena terlihat lebih cerah dibanding yang dilakukan penambahan sari buah pisang dengan warna krem atau lebih pekat. Hal ini terbukti dengan hasil uji kalorimeter, yogurt T0 (tanpa penambahan pisang) $\mathrm{L}^{*}$ mempunyai nilai yang paling tinggi, yang berarti kecerahannya paling tinggi. Penelitian Aprilia et al. (2019) juga menghasilkan warna yang agak kecoklatan pada cocogurt dengan penambahan pisang, hal ini disebabkan prebiotik pisang mengalami proses pencoklatan (browning).

Penelitian ini sejalan dengan hasil penelitian Azzahra dan Nisa (2016) panelis lebih menyukai yogurt dengan penampilan yang lebih cerah (dengan sedikit penambahan pisang), karena dengan penambahan pisang akan memekatkan warna. Warna pekat tersebut hasil dari reaksi browning enzimatik yang terjadi pada pengolahan pisang, karena enzim dapat kontak dengan substrat berupa asam amino tirosin dan komponen fenolik sehingga dapat teroksidasi dan merubah warna menjadi kecoklatan.

\section{Uji Organoleptik Kekentalan}

Hasil analisis uji organoleptik kekentalan dapat dilihat di Tabel 6.
Tabel 6. Hasil anailis uji organoleptik kekentalan yogurt

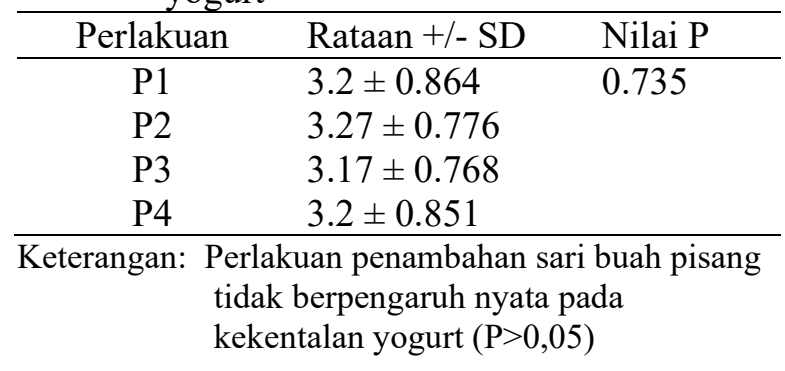

Berdasarkan data yang terdapat pada Tabel 6, dapat diketahui bahwa terdapat perbedaan yang tidak nyata $(\mathrm{P}>0,05)$ pada penambahan sari buah pisang Ambon. Hasil uji kekentalan panelis menilai yogurt berada pada kekentalan yang biasa menuju ke kental seperti yogurt pada umumnya di pasaran. Begitu pula dilihat dari rataan hasil nilai uji organoleptik, panelis menilai semua yogurt kekentalannya hampir sama atau tidak ada pengaruh yang nyata dari perlakuan penambahan sari buah pisang Ambon.

Menurut Ichwansyah (2014) SNI Mutu Yoghurt (Badan Stadarisasi Nasional 2009), tidak terdapat nilai baku kekentalan produk yoghurt, sehingga uji kekentalan hanya dibandingkan dengan konsistensi dan penampakan yoghurt pada SNI Mutu Yoghurt. Roberfroid (2005) dalam Ichwansyah (2014), penambahan inulin ke dalam yoghurt dapat meningkatkan viskositas dan penggumpalan curd, dapat menghasilkan flavor dan tekstur yang lembut, meningkatkan kekentalan yoghurt, mempertahankan warna, dan dapat mengurangi terjadinya sineresis.

\section{KESIMPULAN}

Berdasarkan hasil penelitian ini, dapat disimpulkan bahwa perlakuan penambahan sari buah pisang Ambon sebanyak 0, 2, 4 dan 6\% tidak berpengaruh nyata terhadap sifat fisik warna $\left(\mathrm{L}^{*} \mathrm{a} \mathrm{b}^{*}\right)$ dan total padatan yogurt. Apabila dilihat dari nilai rataannya dengan kenaikan penambahan sari buah pisang Ambon akan mengurangi kecerahan yogurt, warna dari kehijauan berkurang dan menuju ke merah, dan warna semakin menuju kekuningan, total padatan juga mengalami kenaikan. Hasil uji analisis organoleptik terhadap warna terjadi pengaruh yang nyata antara perlakuan T0 (tanpa penambahan sari buah pisang Ambon) dengan T1, T2 dan T3, namun antara penambahan sari buah pisang Ambon 2, 4, dan 6\% tidak terdapat pengaruh yang nyata. Perlakuan penambahan 
tidak terjadi pengaruh yang nyata terhadap uji organoleptik kekentalan yogurt.

\section{DAFTAR PUSTAKA}

Almatsier, S., 2001. Prinsip Dasar Ilmu Gizi. Jakarta: Gramedia Pustaka Utama.

Aprilia, D., S. Hermalia, R. Rahayu, I. D. Destiana. 2019. Pengaruh Perbedaan Konsentrasi Pisang sebagai Prebiotik Alami dan Pektin terhadap Karakteristik Cocogurt. 10th Industrial Research Workshop and National Seminar, 2019. Jurnal.Polban.ac.id.

Asih, W. R., K. R. Kuswanto, Y. A. Widanti, 2018. Penambahan Puree Daun Kelor (Moringa oleifera) dan Puree Pisang Ambon untuk Formula MPASI (Makanan Pendamping ASI). Jurnal Teknologi dan Industri Pangan 3 (1): 1017.

Azzahra, F. dan C. Nissa, 2017. Karakteristik Mutu dan Sensorik Pangan Fungsional: Stirred Yoghurt Tersubstitusi Madu dan Pure Pisang Ambon (Musa paradisiaca) dengan Menggunakan Inokulum Lactobacillus rhamnosus. Undergraduate thesis, Diponegoro University. http://eprints.undip.ac.id/62132/

Bouhnik, Y., L. Achour, D. Paineau, M. Riottot, A. Attar, dan F. Bornet. 2007. Fourweek short chain fructo oligosaccharides ingestion leads to increasing fecal bifidobacteria and cholesterol excretion in healthy elderly volunteers. Nutr. J; 6:42, doi:10.1186/1475-2891-6-42.

Fardiaz, S. 2003. Mikrobiologi Pangan. Gramedia Pustaka Utama. Jakarta.

Gahruie, H. H., M. H. Eskandaria., G. Mesbah., and M. A. Hanifpour. 2015. Scientific and technical aspects of yogurt fortification: a review. Food Science and Human Wellness. 4(1): 1-8.

Gibson, G. R., H. M. Probert, J. Van Loo, R.A. Rastall and M. Roberfroid. 2004. Dietary modulation of the human colonic microbiota: updating the concept of prebiotics. Nutrition Research Reviews. 17: $259-275$.

Haryatmi, D., O. P. Astirin, T. Widiyani, 2017. Aktivitas Versimidial dan Ovisidal dari Buah Pisang Ambon (Musa paradisiaca var. sapientum (L.) terhadap Cacing Ascarissuum secara In Vitro. Prosiding Seminar Nasional Pendidikan Sains (SNPS) 2017. Universitas Sebelas Maret Surakarta, 26 Oktober 2017.

Ichwansyah, R. 2014. Pengembangan Yogurt Sinbiotik Plus Berbasis Puree Pisang Ambon (Musa paradisiaca L.) Dengan Penambahan Inulin sebagai Alternatif Pangan Fungsional. Skripsi. Departemen Gizi Masyarakat. Fakultas Ekologi Manusia. Institut Pertanian Bogor.

Ismawati, N., Nurwantoro, Y. B. Pramono, 2016. Nilai pH, Total Padatan Terlarut, dan Sifat Sensoris Yogurt dengan Penambahan Ekstrak Bit (Beta vulgaris L.). Jurnal Aplikasi Teknologi Pangan. 5 (3): 89-93. DOI : http://dx.doi.org/10.17728/jatp.181.

Karlin, R., A. Rahayuni, 2014. Potensi Yogurt Tanpa Lemak dengan Penambahan Tepung Pisang dan Tepung Gembili Sebagai Alternatif Menurunkan Kolesterol. Journal of Nutrition College 3 (2): 16-25.

Novidahlia, N., G. P. Pangandian, dan Aminullah. 2018. Karakteristik Red smoothies dari Buah Pisang Ambon dan Naga Merah dengan Penambahan CMC (Carboxymethyl cellulose). Jurnal Agroindustri Halal. 4 (2): 183-191.

Robefroid, M., 2005. Inulin-type fructans : Functional food ingredients. CRC Press, Florida.

Wahyudi, 2006. Proses Pembuatan dan Analisis Mutu Yoghurt. Buletin Teknik Pertanian 11 (1): 12-16.

Wibawanti, J. M. W., dan Rinawidiastuti, 2018. Sifat Fisik dan Organoleptik Yogurt Drink Susu Kambing Dengan Penambahan Ekstrak Kulit Manggis 
(Garcinia mangostana L.). Jurnal Ilmu dan Teknologi Hasil Ternak. 13 (1) :2737. DOI 10.21776/ub.jitek.2018.013.01.3.

Widagdha, S., dan F.C. Nisa. 2015. Pengaruh Penambahan Sari Anggur (Vitis vinifera
L.) dan Lama Fermentasi terhadap Karakteristik Fisiko Kimia Yogurt. Jurnal Pangan dan Agroindustri 3 (1): 248-258. 